\title{
Comprehensive Proteome Analysis of the Excretory/Secretory Proteins of Toxoplasma gondii
}

\author{
Won-Kyu Lee, Hye-Jin Ahn, ${ }^{\dagger}$ Je-Hyun Baek, ${ }^{\ddagger}$ Chong-Heon Lee, ${ }^{\#}$ Yeon Gyu Yu, ${ }^{*}$ and Ho-Woo Nam ${ }^{\dagger,}$ \\ Department of Chemistry, College of Natural Sciences, Kookmin University, Seoul 136-702, Korea \\ *E-mail:ygyu@kookmin.ac.kr \\ ${ }^{\dagger}$ Department of Parasitology and the Catholic Institute of Parasitic Diseases, College of Medicine, \\ Catholic University of Korea, Seoul 137-701, Korea. "E-mail: howoo@catholic.ac.kr \\ ${ }^{*}$ Center of Biomedical Mass Spectrometry (CBMS), Diatech Korea Co., Ltd., Seoul 138-826, Korea \\ \# Department of Oral Pathology, College of Dentistry, Dankook University, Cheonan 330-714, Korea \\ Received July 5, 2014, Accepted July 26, 2014
}

\begin{abstract}
Proteomic analyses of the excretory/secretory proteins from the RH strain of Toxoplasma gondii have been performed to understand their functions in the host-parasite interaction. A total of 34 proteins were identified from LC/MS/MS analysis and their abundance was estimated by spectral counting methods. Among them, 8 species of micronemal proteins (MICs), 2 species of rhoptry proteins (ROPs), and 6 species of dense granular proteins (GRAs) were confirmed. Besides these, 18 species of protein were newly identified, and their cellular functions were estimated from sequence analysis. The three most abundant of the 34 identified extractor/ secretory proteins-GRA1, GRA7 and GRA2-were confirmed to be highly expressed in $T$. gondii using the spectral count method. This phenomenon is another demonstration of the importance of GRA proteins for the penetration and survival of $T$. gondii.
\end{abstract}

Key Words : Excretory/secretory protein, Toxoplasma gondii, Micronemal protein, Rhoptry protein, Dense granule protein

\section{Introduction}

Toxoplasma gondii is a member of Apicomplexa phylum and is the causative agent of toxoplasmosis. ${ }^{1}$ It is a widely distributed protozoan parasite that infects various warmblooded animals, including humans. Decoster et al. (1988) first described several excretory and secretory antigens (ESAs) of $T$. gondii in the sera of toxoplasmosis patients. ${ }^{2}$ ESA have been studied with regard to cell-mediated immunity, ${ }^{3-6}$ cell biology, ${ }^{7-10}$ and biochemical process. ${ }^{11,12}$ Most ESAs of $T$. gondii are released from highly specialized secretory organelles such as micronemes, rhoptries, and dense granules, which are involved in the penetrating process and the intracellular interactions within the parasitophorous vacuole (PV). The micronemes secrete a collection of adhesion proteins, termed microneme proteins (MICs) that mediate host cell entry. ${ }^{13-15}$ Rhoptry proteins (ROPs) and lipids form the junction moving during invasion, ${ }^{16}$ eventually resulting in a parasitophorous vacuole that enables the efficient procurement of nutrients and the evasion of host immune defenses. ${ }^{17,18}$ Dense granule proteins (GRAs) appear to facilitate the formation of specialized tubules that enable nutrient acquisition by the parasite, and some of these proteins, most notably GRA7, are also secreted into host cells. ${ }^{19}$ ROPs are also injected into the host cell, resulting in the extensive modification of host gene expression and signaling pathways. ${ }^{20}$ Eui-Sun Son and Ho woo Nam (2001), attempted to profile the production, subcellular localization, and exhaustion of excretory/secretory proteins (ESPs). This demonstrates that they play an essential role in providing the appropriate environment for the entry of the parasite into host cells. ${ }^{21}$ A couple of proteins have been identified in ESP including a $42 \mathrm{kD}$ protease, ${ }^{22}$ GRA3 and GRA10. ${ }^{23}$ In a recent report on ESP, manipulation of the host PI3K/Akt signaling pathway and Nox4 gene expression is influenced by ESP, and this mechanism is involved in T. gondii survival and proliferation. ${ }^{24}$

Using two dimensional electrophoresis (2DE) and multidimensional protein identification technology, approximately 100 spots of ESPs related to host cell invasion could be identified. Many proteins were present in multiple spots, consistent with the presence of post-translational modifications. ${ }^{25,26}$ In a similar study, A23187 used to stimulate calcium mediated ESP from T. gondii. As a result, total of 213 protein spots were identified by 2 DE. ${ }^{27}$ Purified microneme proteins, which play in long or short range interactions during parasite attachment and entry, have also been analyzed using proteomic techniques. ${ }^{28,29}$ Although there has been a substantial amount of T. gondii proteomics research, an extensive study on the identification of ESPs has not been reported.

In this study, we performed proteomic analysis of ESPs in the RH strain of T. gondii, identified 34 proteins, and analyzed their abundance.

\section{Experimental}

Chemicals. Acrylamide and bis-acrylamide cocktail solu- 
tions were obtained from Bio-Rad (USA). The chemicals 3[(3-cholamidopropyl)dimethylammonio]-1-propanesulfonate (CHAPS), and dithiothreitol (DTT) were purchased from GE Healthcare (USA). Urea, thiourea, iodoacetamide, and the other reagents for the polyacrylamide gel preparation were from Sigma (USA). All other chemicals were acquired from standard sources and were of molecular biology grade or higher.

Preparation of ESP. The RH strain of $T$. gondii was maintained by peritoneal passages in Balb/c mice. Tachyzoites were purified by centrifugation over $40 \%$ Percoll (GE Healthcare, USA) in PBS solution. ${ }^{21}$ Purified tachyzoites $\left(3 \times 10^{8}\right)$ were incubated at $37^{\circ} \mathrm{C}$ for $1 \mathrm{~h}$ under mild agitation in $1.0 \mathrm{~mL}$ Hank's balanced salt solution (Gibco BRL, USA). After centrifugation for $5 \mathrm{~min}$ at $6,000 \mathrm{rpm}$, the supernatant containing ESPs was recovered.

Western Blot Analysis. ESPs were separated in $12 \%$ SDS-PAGE gels and transferred onto nitrocellulose sheets (NC, Schlleicher and Shuell, Keene, USA). NC papers blocked by $5 \%$ skim milk in PBS $/ 0.05 \%$ Tween- 20 were incubated with total anti-T. gondii polyclonal antibody diluted 1:1,000, and then with 1:3,000 diluted HRP-conjugated goat antimouse IgG antibody (Cappel, Costa Mesa, USA). They were soaked in enhanced chemiluminescence (ECL) solution (Intron, Korea) for $1 \mathrm{~min}$ and exposed to an X-ray film for visualization (Konica, Japan).

Enzymatic In-gel Digestion. The proteins separated by SDS-PAGE were excised from the gel, and the gel pieces containing protein were destained with $50 \%$ acetonitrile (ACN) containing $50 \mathrm{mM} \mathrm{NH} \mathrm{NHCO}_{3}$ and vortexed until $\mathrm{CBB}$ was completely removed. These gel pieces were then dehydrated in $100 \%$ acetonitrile and Vacuum-dried for 20 min in CentriVap ${ }^{\circledR}$ DNA Centrifugal concentrator. For the digestion, gel pieces were reduced using $10 \mathrm{mM}$ DTT in 50 $\mathrm{mM} \mathrm{NH} \mathrm{HCO}_{3}$ for $45 \mathrm{~min}$ at $56^{\circ} \mathrm{C}$, followed by alkylation by $55 \mathrm{mM}$ iodoacetamide in $50 \mathrm{mM} \mathrm{NH}_{4} \mathrm{HCO}_{3}$ for $30 \mathrm{~min}$ in dark. Finally, each gel pieces were treated with $12.5 \mathrm{ng} / \mu \mathrm{L}$ sequencing grade modified trypsin (Promega, USA) in 50 $\mathrm{mM} \mathrm{NH} \mathrm{NHCO}_{3}$ buffer (pH 7.8) at $37^{\circ} \mathrm{C}$ for overnight. Following digestion, tryptic peptides were extracted with $5 \%$ formic acid in $50 \%$ ACN solution at room temperature for $20 \mathrm{~min}$. The supernatants were collected and dried by CentriVap $^{\circledR}$ DNA Centrifugal concentrator. The samples were purified and concentrated in $0.1 \%$ formic acid using StageTip C18 (Thermo, German) before MS analysis.

Liquid Chromatography and Mass Spectrometric Analysis. The tryptic peptides were loaded onto a fused silica microcapillary column $(12 \mathrm{~cm} \times 75 \mu \mathrm{m})$ packed with C18 reversed phase resin $(5 \mu \mathrm{m}, 100 \AA)$. LC separation was conducted under a linear gradient as follows: a 3-40\% solvent $\mathrm{B}(0.1 \%$ formic acid in $100 \% \mathrm{ACN})$ gradient, with a flow rate of $400 \mathrm{~nL} / \mathrm{min}$ for $60 \mathrm{~min}$. The column was directly connected to an LTQ linear ion-trap mass spectrometer (Finnigan, USA) equipped with a nano-electrospray ion source. The electrospray voltage was set at $1.80 \mathrm{kV}$, and the threshold for switching from MS to MS/MS was 2000. The normalized collision energy for MS/MS was $35 \%$ of the main radio frequency amplitude (RF) and the duration of activation was $30 \mathrm{~ms}$. All spectra were acquired in datadependent scan mode. Each full MS scan was followed by five consecutive MS/MS scans corresponding to the five most intense peaks in the full MS scan. Repeat count of peaks for dynamic exclusion was 1 , and its repeat duration was $30 \mathrm{sec}$. The dynamic exclusion duration was set to 180 sec and the width of exclusion mass was $\pm 1.5 \mathrm{Da}$. The list size of dynamic exclusions was 50 .

Database Searching. All MS/MS samples were analyzed using SEQUEST (Thermo Fisher Scientific, USA; version v.27, rev. 11). SEQUEST was searched with a fragment ion mass tolerance of 1.00 Da and a parent ion tolerance of 3.0 Da. Carbamidomethylation of cysteine was specified in SEQUEST as a fixed modification. Oxidation of methionine was specified in SEQUEST as a variable modification. Scaffold (version Scaffold_4.2, Proteome Software Inc., USA) was used to validate $\overline{M S} / \mathrm{MS}$ based peptide and protein identifications (Peptide/Protein FDR 1\%) which contained at least 2 identified peptides. SEQUEST was used to search the TgondiiRH_ORFs_Anotated_GRA_ROP_MIC_Uniprot _Mouse_Contaminants.fasta database $(248,268$ entries including decoy sequences) assuming that the peptide fragments were resulted from trypsin digestion. The $T$. gondii $\mathrm{RH}$ protein database was reconstructed with TgondiiRH ORFs fasta (from http://toxodb.org/toxo/showApplication.do), GRA/ROP/MIC.fasta, and mouse.fasta from UniportKB (http://www.uniprot.org). The protein abundance and rank estimation were defined by the previously described $F_{a b b}$ index. ${ }^{30,31}$

The putative function of proteins, which were not listed in UniProtKB, was further analyzed using Pfam (http://pfam.

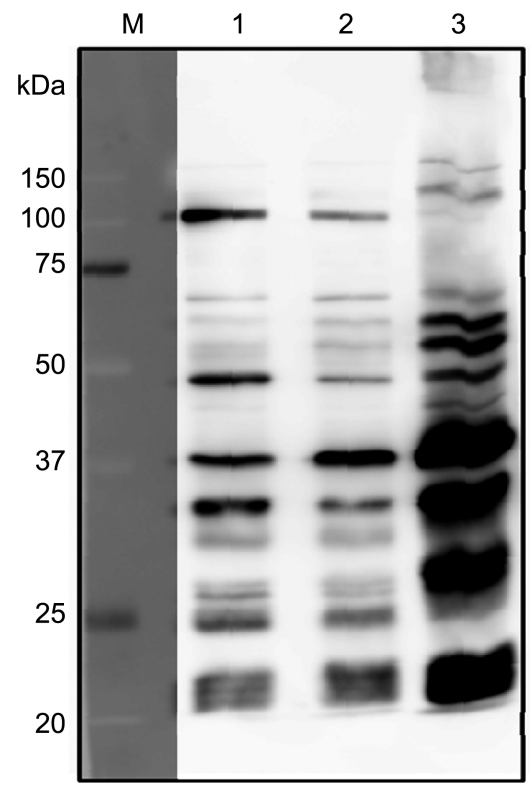

Figure 1. Western blot analysis of the ESPs of the Toxoplasma gondii $(\mathrm{RH})$ strain. The ESP bands on nitrocellulose membrane were reacted with a reference serum from a mouse infected with RH tachyzoites. ESP bands were detected by anti $T$. gondii polyclonal antibody. M, size marker; lane 1 and 2, two-batch samples of ESP; lane 3, Total T. gondii lysate. 
xfam.org) and gene ontology databases (http://www.ebi.ac. uk/ego/).

Criteria for Protein Identification. Scaffold (version Scaffold_4.3.2, Proteome Software Inc., USA) was used to validate $\mathrm{MS} / \mathrm{MS}$ based peptide and protein identifications. Peptide identifications were accepted if they could be established at greater than $81.0 \%$ probability to achieve a false discovery rate (FDR) less than $1.0 \%$ by the Scaffold Local FDR algorithm. Protein identifications were accepted if they could be established at greater than $98.0 \%$ probability to achieve an FDR less than $1.0 \%$ and contained at least 2 identified peptides. Protein probabilities were assigned by the Protein Prophet algorithm. ${ }^{32}$ Proteins that contained similar peptides and could not be differentiated based on MS/MS analysis alone were grouped to satisfy the principles of parsimony.

\section{Results and Discussion}

Western Blot Analysis. When detected using an anti T. gondii polyclonal antibody, about 20 bands appeared in the total ESP from T. gondii (Fig. 1). We confirmed proper separation of ESP using western blot analysis results compared with a reference. ${ }^{21}$ The molecular mass of 15 ESP were estimated as $110,97,86,80,70,60,54,42,40,36,30$, $28,26,22$, and $19 \mathrm{kD}$, which were compatible with the previously described ESA of $T$. gondii, ${ }^{3,4}$ with minor differences. The protein samples identified by western blot analysis were stored at $-80^{\circ} \mathrm{C}$ until analyzed.

Identification of ESP by LC/MS/MS Analysis. The ESPs were digested by trypsin and the resulting peptides were analyzed by LC/MS/MS. A total of 314 proteins were identified by MS analysis. Among them, 280 proteins were

Table 1. The list of identified proteins found in ESP of Toxoplasma gondii

\begin{tabular}{|c|c|c|c|c|c|c|}
\hline $\begin{array}{c}\text { Rank } \\
\text { (by Abundance) }\end{array}$ & $\begin{array}{c}\text { Identified Proteins } \\
\qquad(34 / 314)\end{array}$ & $\begin{array}{c}\text { Molecular } \\
\text { Weight }(\mathrm{kDa})\end{array}$ & $\begin{array}{c}\text { \# of Unique } \\
\text { Peptides (1st) }\end{array}$ & $\begin{array}{c}\text { \# of Unique } \\
\text { Peptides (2nd) }\end{array}$ & $\begin{array}{c}\text { \# of Total Spectra } \\
\text { (merged) }\end{array}$ & $\begin{array}{c}\text { \# of Estimated Protein } \\
\text { Abundance }\end{array}$ \\
\hline 1 & GRA1 & 20 & 10 & 11 & 275.48 & 232.75 \\
\hline 2 & GRA7 & 26 & 10 & 10 & 152.12 & 98.86 \\
\hline 3 & GRA2 & 20 & 6 & 6 & 108.61 & 91.77 \\
\hline 4 & TgESP-1 & 36 & 9 & 15 & 155.91 & 73.18 \\
\hline 5 & MIC2 & 83 & 19 & 19 & 265.67 & 54.09 \\
\hline 6 & MIC5 & 20 & 6 & 4 & 52.59 & 44.43 \\
\hline 7 & TgESP-2 & 13 & 1 & 3 & 29.67 & 38.57 \\
\hline 8 & TgESP-3 & 10 & 1 & 2 & 20.49 & 34.63 \\
\hline 9 & TgESP-4 & 15 & 4 & 4 & 28.44 & 32.04 \\
\hline 10 & $T g E S P-5$ & 36 & 2 & 9 & 66.01 & 30.99 \\
\hline 11 & MIC10 & 23 & 5 & 4 & 34.18 & 25.11 \\
\hline 12 & $T g E S P-6$ & 20 & 3 & 3 & 27.16 & 22.95 \\
\hline 13 & TgESP-7 & 64 & 13 & 13 & 82.66 & 21.83 \\
\hline 14 & TgESP-8 & 16 & 1 & 2 & 20.45 & 21.59 \\
\hline 15 & GRA5 & 13 & 3 & 4 & 14.21 & 18.47 \\
\hline 16 & MIC17A & 39 & 9 & 6 & 42.10 & 18.24 \\
\hline 17 & TgESP-9 & 19 & 0 & 5 & 20.12 & 17.89 \\
\hline 18 & MIC11 & 22 & 4 & 3 & 20.87 & 16.03 \\
\hline 19 & GRA6 & 24 & 2 & 4 & 21.30 & 15.00 \\
\hline 20 & $T g$ ESP-10 & 17 & 2 & 3 & 14.23 & 14.15 \\
\hline 21 & MIC1 & 42 & 5 & 6 & 35.11 & 14.12 \\
\hline 22 & MIC6 & 37 & 4 & 3 & 25.02 & 11.43 \\
\hline 23 & GRA4 & 36 & 0 & 2 & 20.12 & 9.44 \\
\hline 24 & TgESP-11 & 13 & 1 & 2 & 7.12 & 9.25 \\
\hline 25 & TgESP-12 & 75 & 4 & 5 & 33.42 & 7.53 \\
\hline 26 & TgESP-13 & 14 & 1 & 2 & 5.43 & 6.56 \\
\hline 27 & TgESP-14 & 14 & 0 & 2 & 3.77 & 4.55 \\
\hline 28 & TgESP-15 & 16 & 0 & 2 & 3.77 & 3.98 \\
\hline 29 & TgESP-16 & 35 & 1 & 2 & 5.43 & 2.62 \\
\hline 30 & TgESP-17 & 27 & 2 & 1 & 3.75 & 2.35 \\
\hline 31 & ROP15 & 34 & 0 & 3 & 3.77 & 1.87 \\
\hline 32 & ROP2 & 475 & 7 & 9 & 42.20 & 1.50 \\
\hline 33 & MIC8 & 75 & 2 & 1 & 5.41 & 1.22 \\
\hline 34 & TgESP-18 & 28 & 2 & 0 & 1.66 & 1.00 \\
\hline
\end{tabular}


identified as mouse proteins and only 34 proteins were confirmed to be derived from $T$. gondii. The reason was that the ESP were obtained from the abdominal cavity of mice. Mice proteins outnumbered T. gondii by far, therefore ESP identification was difficult, relatively. The 34 identified proteins are listed in Table 1 along with protein name, molecular weight, number of unique peptides, number of total spectra, number of estimated protein copy and rank by abundance. Among them, 16 proteins registered in the UniProtKB were listed in Table 2 along with protein name, alternative name, UniProtKB ID, function by Gene Ontology database, and reference. A total of 18 species of protein, including $T g E S P-1$, were newly identified in this study. The amino acid sequences of these 18 proteins were described in Support Information 1.

Among the identified proteins, proteins related to the hostparasite interaction were of particular interest. All components of ESP are known to be released from highly specialized secretory organelles of $T$. gondii, micronemes (Micronemal protein, MIC), rhoptries (Rhoptry protein, ROP), and dense granules (Dense granule protein, GRA), which function in the penetrating process and during subsequent intracellular interactions within the parasitophorous vacuole (PV). From these proteins, 8 species of MIC protein, 2 species of ROP protein, and 6 species of GRA protein were identified (Table 2). The Gene Ontology database functions of these proteins are antigen presenting in the extracellular region, the factors of transport vesicles, and pathogenesis. The ROP2 protein has a kinase domain, and it is believed to be involved in protein phosphorylation.

The frequencies of the 34 proteins from $T$. gondii were further analyzed using the spectral count method and the abundances of the proteins are listed in Table 1. GRA1 is the most abundant protein followed by GRA7 and GRA2. Interestingly, the top 3 abundant proteins are all GRA proteins. The GRA1 protein is considerably more abundant than the other 33 kinds of identified proteins, and is more than double the abundance of GRA7 or GRA2. GRA1 has been reported to be useful as a diagnostic marker for chronic toxoplasmosis and vaccine development. ${ }^{33}$ In the case of GRA7, the $T$. gondii actively recruits host microtubules, resulting in the selective attraction of endo-lysosomes to the PV. GRA7 acts like a lasso that sequesters host endocytic organelles in the vacuolar space. ${ }^{19}$ The expression of GRA1 and GRA7 is much higher than the other proteins, and the function of these proteins shows their considerable importance for interactions with the host system. Some of these GRAs have been shown to be targeted to the parasitophorous vacuolar space, the parasitophorous vacuole membrane or the intravacuolar tubular network where they play significant roles in the biogenesis and modification of the parasitophorous vacuole where it interfaces with the host cell. ${ }^{33}$ $T g$ ESP-1, the $4^{\text {th }}$ most abundant protein out of our identified ESPs, it has a similar sequence to elongation factor 1-alpha, suggesting it is involved in protein synthesis. We can infer that ESPs, including TgESP-1, are involved in the synthesis

Table 2. The list of reported protein on UniProtKB

\begin{tabular}{|c|c|c|c|c|}
\hline Name & Alternative name & UniProt ID & Function & Reference \\
\hline GRA1 & Major antigen p24 & P13403 & Extracellular region & Cesbron-Delauw et al. $(1989)^{35}$ \\
\hline GRA7 & $\begin{array}{l}29 \mathrm{kDa} \text { excretory dense } \\
\text { granule protein }\end{array}$ & O00933 & $\begin{array}{c}\text { Integral component of membrane } \\
\text { Transport vesicle }\end{array}$ & Hans-Georg $(1998)^{36}$ \\
\hline GRA2 & $28 \mathrm{kDa}$ antigen & P13404 & Symbiont-containing vacuole & Mercier et al. $(1989)^{37}$ \\
\hline MIC2 & & O00816 & None & Wan et al. $(1997)^{38}$ \\
\hline MIC5 & & V4ZHQ9 & None & Saouros et al. $(2012)^{39}$ \\
\hline MIC10 & $20 \mathrm{kDa}$ excretory-secretory antigen & B9PRE4 & None & Hoff et al. $(2001)^{40}$ \\
\hline GRA5 & $\mathrm{p} 21$ & Q07828 & $\begin{array}{c}\text { Integral component of membrane } \\
\text { Transport vesicle }\end{array}$ & Lecordier et al. $(1993)^{41}$ \\
\hline MIC17A & & V4Z8E3 & $\begin{array}{c}\text { Blood coagulation } \\
\text { Proteolysis } \\
\text { Extracellular region }\end{array}$ & \\
\hline MIC11 & & B9PUW8 & None & Harper et al. $(2004)^{42}$ \\
\hline GRA6 & Antigen $\mathrm{p} 32$ & Q27003 & $\begin{array}{l}\text { Integral component of membrane } \\
\text { Transport vesicle }\end{array}$ & Lecordier et al. $(1995)^{43}$ \\
\hline MIC1 & & O00834 & $\begin{array}{l}\text { Cell adhesion } \\
\text { Pathogenesis }\end{array}$ & Fourmaux et al. $(1996)^{44}$ \\
\hline MIC6 & & Q9XYH7 & $\begin{array}{l}\text { Cell adhesion } \\
\text { Pathogenesis }\end{array}$ & Reiss et al. $(2001)^{45}$ \\
\hline GRA4 & Antigen H11 & Q27002 & $\begin{array}{c}\text { Integral component of membrane } \\
\text { Transport vesicle }\end{array}$ & Mevelec et al. $(1992)^{46}$ \\
\hline ROP15 & & A4GWX6 & None & \\
\hline ROP2 & & Q06AK3 & $\begin{array}{c}\text { ATP binding } \\
\text { Protein kinase activity }\end{array}$ & Qiu et al. (2009) ${ }^{47}$ \\
\hline MIC8 & & D8UY25 & None & Kessler et al. $(2008)^{48}$ \\
\hline
\end{tabular}


Table 3. The list of novel reported proteins

\begin{tabular}{|c|c|c|c|c|}
\hline Name & Location & Domain & Similar protein & Putative function \\
\hline TgESP-1 & TGRH_chrIa:1271142-1272140(-) & $\begin{array}{l}\text { Elongation factor Tu GTP binding } \\
\text { domain } \\
\text { Elongation factor Tu domain } 2 \\
\text { Elongation factor Tu C-terminal domain }\end{array}$ & Elongation factor 1-alpha & Protein biosynthesis \\
\hline TgESP-2 & TGRH_chrIa:634885-635256(-) & None & Putative profilin & $\begin{array}{l}\text { Actin cytoskeleton } \\
\text { organization }\end{array}$ \\
\hline TgESP-3 & TGRH_chrIa:634582-634851(-) & None & Inflammatory profilin & $\begin{array}{l}\text { Actin cytoskeleton } \\
\text { organization }\end{array}$ \\
\hline TgESP-4 & TGRH_chrIa:1272355-1272774(-) & $\begin{array}{c}\text { Elongation factor Tu GTP binding } \\
\text { domain }\end{array}$ & Elongation factor 1-alpha & Protein biosynthesis \\
\hline TgESP-5 & TGRH_chrIb:1038884-1039867(+) & Actin & Actin ACT1 & Cytoskeleton \\
\hline TgESP-6 & TGRH_chrIb:754143-754679(-) & $\begin{array}{l}\text { Kazal-type serine protease inhibitor } \\
\text { domain }\end{array}$ & $\begin{array}{l}\text { Tachyzoite serine } \\
\text { proteinase inhibitor }\end{array}$ & None \\
\hline TgESP-7 & TGRH_chrIb:571277-573040(+) & PAN domain & Microneme protein MIC4 & $\begin{array}{l}\text { Blood coagulation } \\
\text { Proteolysis }\end{array}$ \\
\hline TgESP-8 & TGRH_chrIb:752726-753154(-) & $\begin{array}{l}\text { Kazal-type serine protease inhibitor } \\
\text { domain }\end{array}$ & $\begin{array}{l}\text { Tachyzoite serine } \\
\text { proteinase inhibitor }\end{array}$ & None \\
\hline TgESP-9 & TGRH_chrIa:743195-743719(+) & Thioredoxin & Thioredoxin & Oxidoreductase \\
\hline TgESP-10 & TGRH_chrIb:1040267-1040731(+) & Actin & Actin ACT1 & Cytoskeleton \\
\hline TgESP-11 & TGRH_chrIa:827883-828242(+) & $\begin{array}{l}\text { Glucose-6-phosphate dehydrogenase, } \\
\text { C-terminal domain }\end{array}$ & $\begin{array}{l}\text { Glucose-6-phosphate } \\
\text { 1-dehydrogenase }\end{array}$ & $\begin{array}{l}\text { Carbohydrate } \\
\text { metabolism }\end{array}$ \\
\hline $\operatorname{TgESP}-12$ & TGRH_chrIb:1811657-1813663(+) & $\begin{array}{l}\text { RNA recognition motif-containing } \\
\text { protein }\end{array}$ & $\begin{array}{l}\text { RNA recognition motif } \\
\text { WW domain }\end{array}$ & Nucleotide binding \\
\hline TgESP-13 & TGRH_chrIb:1231496-1231858(-) & Ribosomal protein S28e & Ribosomal protein RPS 28 & Translation \\
\hline TgESP-14 & TGRH_chrIa:1939363-1939734(-) & Nucleoside diphosphate kinase & $\begin{array}{l}\text { Nucleoside diphosphate } \\
\text { kinase, putative }\end{array}$ & $\begin{array}{l}\text { CGU/TP biosynthetic } \\
\text { process }\end{array}$ \\
\hline $\operatorname{TgESP}-15$ & TGRH_chrIb:1813125-1813553(+) & RNA recognition motif. & $\begin{array}{l}\text { RNA recognition motif- } \\
\text { containing protein }\end{array}$ & Nucleotide binding \\
\hline TgESP-16 & TGRH_chrIb:1686978-1687934(-) & $\begin{array}{l}\text { Cytochrome C and Quinol oxidase } \\
\text { polypeptide I }\end{array}$ & $\begin{array}{l}\text { Hyaluronan/mRNA-bind- } \\
\text { ing family protein }\end{array}$ & None \\
\hline TgESP-17 & TGRH_chrIb:74822-75550(-) & None & None & None \\
\hline TgESP-18 & TGRH_chrIa:757447-758244(+) & None & $\begin{array}{l}\text { Sporozoite protein with an } \\
\text { altered thrombospondin } \\
\text { repeat SPATR }\end{array}$ & None \\
\hline
\end{tabular}

or modification of host proteins. GRA proteins are potent antigens that can induce strong parasite-directed T-cell and B-cell responses. ${ }^{34}$ Because of the abundance of their expression, the proteins GRA1, GRA2, GRA7 and TgESP-1 deserve to be considered as promising candidates for vaccine development.

Functional Estimation of Unknown Proteins. The cellular function of 18 newly identified proteins were not listed in the UniProtKB database (Table 3 ). The functions of these proteins were estimated from their structural homologues using the Pfam database, UniProt database, and Gene Ontology database. The putative functions indicated that $T g$ ESP1 and TgESP-4 were involved in protein synthesis; TgESP2, TgESP-3, TgESP-5 and TgESP-10 were involved in the cytoskeleton; $T g$ ESP-7 was involved in blood coagulation and proteolysis; $T g$ ESP-9 was involved in the oxydoreductation reaction; $T g \mathrm{ESP}-11$ was involved in carbohydrate metabolism; $T g$ ESP-12, TgESP-14, and TgESP-15 were involv- ed in nucleotide synthesis; and TgESP-13 was involved in protein translation. TgESP-6 and TgESP-8 have a domain of the Kazal-type serine protease inhibitor, but the function of this domain is not recorded in the GO database. TgESP-16 has a domain common to Cytochrome $\mathrm{C}$ and Quinol oxidase polypeptide I, but the function of this domain is not recorded in the GO database. $T g$ ESP-17 and $T g E S P-18$ do not have a known structural domain. TgESP-1 and TgESP-4 are structurally similar to elongation factor 1-alpha, $T g \mathrm{ESP}-2$ and $T g$ ESP-3 are structurally similar to profilin, TgESP-6 and TgESP-8 are structurally similar to the tachyzoite serine proteinase inhibitor, and TgESP-5 and TgESP-10 are structurally similar to actin. The function of these 18 kinds of proteins, inferred from the structural information, indicates that they are involved in the cytoskeleton, protein synthesis, proteolysis and translation. It can be considered that ESPs from $T$. gondii, including these 18 proteins, are actively involved in protein metabolism. 


\section{Conclusion}

We have analyzed ESPs from $T$. gondii using LC/MS/MS analysis techniques and estimated their abundance using spectral counting methods. A total of 314 proteins were identified, and among those there were 34 proteins identified that are ESPs of T. gondii and 18 of those proteins are novel and reported in this study for the first time. The putative functions of the 18 proteins indicate they are involved in protein metabolism, oxidoreductation, carbohydrate metabolism, and nucleotide binding and protein translation. The 34 proteins identified are listed by abundance, and among the top 3 most abundant proteins are GRA proteins. These quantitative results revealed that GRA proteins are important for the penetration and survival of $T$. gondii. In addition, these high abundant proteins deserve to be considered as promising candidates for anti-parasite drug or vaccine development.

Acknowledgments. This research was supported by MSIP \& PAL, XFEL project, Korea (2014-SB-7) and the Basic Science Research Program through the National Research Foundation of Korea (NRF) funded by the Ministry of Education, Science, and Technology (2012-R1A1A2-002612 and 2013-R1A1A2-062683).

\section{References}

1. Dubey, J. P.; Dubey, J. P. Toxoplasmosis of Animals and Humans, 2nd ed.; CRC Press: Boca Raton, 2010.

2. Decoster, A.; Darcy, F.; Capron, A. Clin. Exp. Immunol. 1988, 73, 376.

3. Darcy, F.; Deslee, D.; Santoro, F.; Charif, H.; Auriault, C.; Decoster, A.; Duquesne, V.; Capron, A. Parasite Immunol. 1988, 10, 553.

4. Duquesne, V.; Auriault, C.; Darcy, F.; Decavel, J. P.; Capron, A. Infect. Immun. 1990, 58, 2120.

5. Rahmah, N.; Anuar, A. K. Biochem. Biophys. Res. Commun. 1992, 187, 294.

6. Zenner, L.; Estaquier, J.; Darcy, F.; Maes, P.; Capron, A.; CesbronDelauw, M. F. Parasite Immunol. 1999, 21, 261.

7. Cesbron-Delauw, M. F.; Capron, A. Res. Immunol. 1993, 144, 41.

8. Ossorio, P. N.; Dubremetz, J. F.; Joiner, K. A. J. Biol. Chem. 1994, $269,15350$.

9. Hoppe, H. C.; Ngo, H. M.; Yang, M.; Joiner, K. A. Nat. Cell Biol. 2000, 2, 449 .

10. Prigione, I.; Facchetti, P.; Lecordier, L.; Deslee, D.; Chiesa, S.; Cesbron-Delauw, M. F.; Pistoia, V. J. Immunol. 2000, 164, 3741.

11. Mercier, C.; Cesbron-Delauw, M. F.; Sibley, L. D. J. Cell Sci. 1998, 111(Pt 15), 2171.

12. Nockemann, S.; Dlugonska, H.; Henrich, B.; Kitzerow, A.; Daubener, W. Mol. Biochem. Parasitol. 1998, 97, 109.

13. Huynh, M. H.; Rabenau, K. E.; Harper, J. M.; Beatty, W. L.; Sibley, L. D.; Carruthers, V. B. EMBO J. 2003, 22, 2082.

14. Cerede, O.; Dubremetz, J. F.; Soete, M.; Deslee, D.; Vial, H.; Bout, D.; Lebrun, M. J. Exp. Med. 2005, 201, 453.

15. Rabenau, K. E.; Sohrabi, A.; Tripathy, A.; Reitter, C.; Ajioka, J. W.; Tomley, F. M.; Carruthers, V. B. Mol. Microbiol. 2001, 41, 537.

16. Alexander, D. L.; Mital, J.; Ward, G. E.; Bradley, P.; Boothroyd, J. C. PLoS Pathog. 2005, 1 , e17.

17. Bradley, P. J.; Ward, C.; Cheng, S. J.; Alexander, D. L.; Coller, S.; Coombs, G. H.; Dunn, J. D.; Ferguson, D. J.; Sanderson, S. J.; Wastling, J. M.; Boothroyd, J. C. J. Biol. Chem. 2005, 280, 34245.

18. Boothroyd, J. C.; Dubremetz, J. F. Nat. Rev. Microbiol. 2008, 6,
79.

19. Coppens, I.; Dunn, J. D.; Romano, J. D.; Pypaert, M.; Zhang, H.; Boothroyd, J. C.; Joiner, K. A. Cell 2006, 125, 261.

20. Bradley, P. J.; Sibley, L. D. Curr. Opin. Microbiol. 2007, 10, 582.

21. Son, E. S.; Nam, H. W. Korean J. Parasitol. 2001, 39, 49.

22. Ahn, H. J.; Song, K. J.; Son, E. S.; Shin, J. C.; Nam, H. W. Biochem. Biophys. Res. Commun. 2001, 287, 630.

23. Ahn, H. J.; Kim, S.; Nam, H. W. Biochem. Biophys. Res. Commun 2005, 331, 614 .

24. Zhou, W.; Quan, J. H.; Lee, Y. H.; Shin, D. W.; Cha, G. H. PloS one 2013, 8, e66306.

25. Zhou, X. W.; Kafsack, B. F.; Cole, R. N.; Beckett, P.; Shen, R. F.; Carruthers, V. B. J. Biol. Chem. 2005, 280, 34233.

26. Fauquenoy, S.; Morelle, W.; Hovasse, A.; Bednarczyk, A.; Slomianny, C.; Schaeffer, C.; Van Dorsselaer, A.; Tomavo, S. Mol. Cell Proteomics 2008, 7, 891.

27. Kawase, O.; Nishikawa, Y.; Bannai, H.; Zhang, H.; Zhang, G.; Jin, S.; Lee, E. G.; Xuan, X. Proteomics 2007, 7, 3718.

28. Carruthers, V. B. Int. J. Parasitol. 2006, 36, 595.

29. Carruthers, V. B.; Tomley, F. M. Subcell. Biochem. 2008, 47, 33.

30. Aye, T. T.; Scholten, A.; Taouatas, N.; Varro, A.; Van Veen, T. A.; Vos, M. A.; Heck, A. J. Mol. Biosyst. 2010, 6, 1917.

31. Scholten, A.; Poh, M. K.; van Veen, T. A.; van Breukelen, B.; Vos, M. A.; Heck, A. J. J. Proteome. Res. 2006, 5, 1435.

32. Nesvizhskii, A. I.; Keller, A.; Kolker, E.; Aebersold, R. Anal. Chem. 2003, 75, 4646.

33. Schwab, J. C.; Beckers, C. J.; Joiner, K. A. Proc. Natl. Acad. Sci. USA 1994, 91, 509.

34. Beghetto, E.; Spadoni, A.; Buffolano, W.; Del Pezzo, M.; Minenkova, O.; Pavoni, E.; Pucci, A.; Cortese, R.; Felici, F.; Gargano, N. Int. J. Parasitol. 2003, 33, 163.

35. Cesbron-Delauw, M. F.; Guy, B.; Torpier, G.; Pierce, R. J.; Lenzen, G.; Cesbron, J. Y.; Charif, H.; Lepage, P.; Darcy, F.; Lecocq, J. P.; Capron, A. Proc. Natl. Acad. Sci. USA 1989, 86, 7537.

36. Fischer, H. G.; Stachelhaus, S.; Sahm, M.; Meyer, H. E.; Reichmann, G. Mol. Biochem. Parasitol. 1998, 91, 251.

37. Mercier, C.; Lecordier, L.; Darcy, F.; Deslee, D.; Murray, A.; Tourvieille, B.; Maes, P.; Capron, A.; Cesbron-Delauw, M. F. Mol. Biochem. Parasitol. 1993, 58, 71.

38. Wan, K. L.; Carruthers, V. B.; Sibley, L. D.; Ajioka, J. W. Mol. Biochem. Parasitol. 1997, 84, 203.

39. Saouros, S.; Dou, Z.; Henry, M.; Marchant, J.; Carruthers, V. B.; Matthews, S. J. Biol. Chem. 2012, 287, 36029.

40. Hoff, E. F.; Cook, S. H.; Sherman, G. D.; Harper, J. M.; Ferguson, D. J.; Dubremetz, J. F.; Carruthers, V. B. Exp. Parasitol. 2001, 97, 77.

41. Lecordier, L.; Mercier, C.; Torpier, G.; Tourvieille, B.; Darcy, F.; Liu, J. L.; Maes, P.; Tartar, A.; Capron, A.; Cesbron-Delauw, M. F. Mol. Biochem. Parasitol. 1993, 59, 143.

42. Harper, J. M.; Zhou, X. W.; Pszenny, V.; Kafsack, B. F.; Carruthers, V. B. Int. J. Parasitol. 2004, 34, 1047.

43. Lecordier, L.; Moleon-Borodowsky, I.; Dubremetz, J. F.; Tourvieille, B.; Mercier, C.; Deslee, D.; Capron, A.; Cesbron-Delauw, M. F. Mol. Biochem. Parasitol. 1995, 70, 85.

44. Fourmaux, M. N.; Achbarou, A.; Mercereau-Puijalon, O.; Biderre, C.; Briche, I.; Loyens, A.; Odberg-Ferragut, C.; Camus, D.; Dubremetz, J. F. Mol. Biochem. Parasitol. 1996, 83, 201.

45. Reiss, M.; Viebig, N.; Brecht, S.; Fourmaux, M. N.; Soete, M.; Di Cristina, M.; Dubremetz, J. F.; Soldati, D. J. Cell Biol. 2001, 152, 563.

46. Mevelec, M. N.; Chardes, T.; Mercereau-Puijalon, O.; Bourguin, I.; Achbarou, A.; Dubremetz, J. F.; Bout, D. Mol. Biochem. Parasitol. 1992, 56, 227.

47. Qiu, W.; Wernimont, A.; Tang, K.; Taylor, S.; Lunin, V.; Schapira, M.; Fentress, S.; Hui, R.; Sibley, L. D. EMBO J. 2009, 28, 969.

48. Kessler, H.; Herm-Gotz, A.; Hegge, S.; Rauch, M.; Soldati-Favre, D.; Frischknecht, F.; Meissner, M. J. Cell Sci. 2008, 121, 947. 